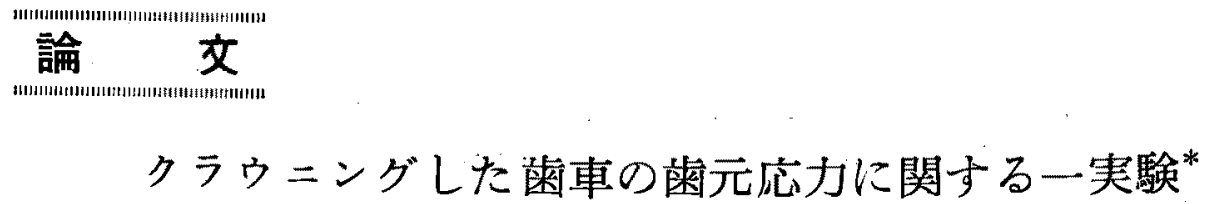

\author{
藤田公明**

\section{An Experiment on the Stress of Traction Gear Having a Great Degree of Crowning}

by

Kōmei FujıTA

(Railway Technical Research Institute, J.N.R.)

\begin{abstract}
As the countermeasure for the teeth failures in the nose-suspended type traction gears of the Japanese National Railways which are caused by the end tooth bearing, the pinions are heavily crowned in order to prevent the end tooth bearing. As the degree of crowning is extremely great, the tooth bearing of such crowned gear is localized and the method of calculation of gear stress in such gear is not established up to the present time.

The author has derived a theoretical method of calculation of gear stress in the heavily crowned gear, and recently conducted an experiment in order to measure the lengthwise distribution of gear stress while the electric locomotive, equipped with a crowned traction gear, was running. The results are as follows :

(1) It was demonstrated by the experiment that, in order to calculate the stress of traction gear which is heavily crowned so as to prevent the end tooth bearing, it would be proper for us to use the solution of the theory about two elastic bodies in contact with each other as the load of tooth face and then to apply the theory of a very long cantilever plate with infinite width.

(2) In this experiment with the ground traction gear of the electric locomotive having the traction motors mounted on bogies and the gears installed rigidly on axles, the distribution of the values of the ratio (dynamically added load+statical load) versus (statical load) was widely scattered due to the high acceleration of the unsprung masses, its maximum value being 2.45 and minimum value 0.85 in the test range of locomotive speeds below $55 \mathrm{~km} / \mathrm{hr}$, namely under $11 \mathrm{~m} / \mathrm{sec}$ of the circumferential speed of pitch circles of gears. (Received Oct. 17, 1959)
\end{abstract}

\section{1. ま え が}

暼動機釣挂装荷している電気車のけん引用歯車は， 釣挂装荷機構が原因で，片当りして，しばしばき裂割 損事故が発生した，そのために最近国鉄では小橧車に レリービングをかねたクラウニングを施している，こ のような爽東ては素当りが極部的であるから，一棣な

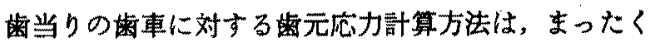
利用できない、したがって，さきにクラウニング崡車 の理論的齿元応力計算方法を導いた。

今回電気機関車用の半可とう式駆動方式に用いられ ているクラウニングした菌車に，静的に集中荷重を作 用させた場合と，機関車が走行している场合について，

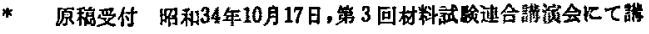
演 (昭 34.9$)$

** 正只 国铁道教得研究的
}

歯筋にそった歯元応力分布状熊を測定して，クラウニ ング事に詨する理論的西元応力䚺算結果と，夷際に 生じる雪元応力とについて比較検討する機会を得た。

\section{2. 供試齿 車}

半可とう式駆動方式の試作台車をもつ国有鉄道の, ED 6115 号電気機関車の大歯車を用いて，静荷重試験 および機関車走行中の底力測定試験を行なった。この 半可とう式駆動方式においては，小粚車は台車に固定 されている電動機の軸端に片持に取りつけられ，大歯 車は車軩に固定されている。したがって，この新しい 形式の歌動方式では，大小歯車間の関係位置は台車わ くと車軸間の相対变位に独がって盌わるので，この相 対変位量をできるだけ少なくするために，軸ばねを在 来のものよりはるかに堅くし，車体と台車間のばねに は空気ばねを使用することにより，車体の車軸に対す 
るばね定数は, 在来のものと同じ程度にして, 動力伝 達機構をきわめて简素化しており，中速度以下の互幹 線用として使用することを目嫩とした，電気機関車用 台車の㗨動方式である.

この駆動方式に用いられている歯車は，大小齿車軸 間に相対变位があるために，片当りによる応力增加を なくすることを目的として，小崡車にのみレリービン グをかねたクラウニングを施している．このクラウニ ングの形状は Fig. 1 に示すとおりで，また，試験を 実施した ED6115 号機関車用の菄車の諸元は Table 1 に示すとおりである.この大歯車の歯元フィレット 中央部に, Fig. 2 のよう抵抗線ひずみ計を沬りつけ， ひずみ計をはりつけられた崡に集中荷重を加えて，静 荷重試験を実施後，機関車に組み込み，ひずみ計のリ 一ト線を車軸端に設けられたスリッブリングに導いて， 歯筋方向 5 所の幾元応力を機関車走行中において同 時に測定した。したがって，以下には大歯車の歯元応 カについてのみ取り扱う.

\section{3. 齿 元応力}

クラウニングを施された歯車の歯元応力計算方法は

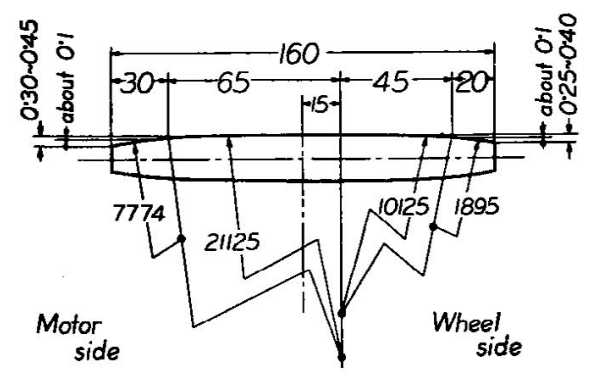

Fig. 1 Shape of crowning on opinion of electric locomotive ED 6115

Table 1 Dimensions of test gears

\begin{tabular}{l|c|c}
\hline Item & Gear & Pinion \\
\hline Number of teeth & 82 & 15 \\
\hline Pressure angle & & 20 \\
\hline Module & & 10 \\
\hline $\begin{array}{c}\text { Pitch diameter (mm) } \\
\text { Face width (mm) }\end{array}$ & 820 & 150 \\
\hline $\begin{array}{c}\text { Amount of profile } \\
\text { shifting (mm) }\end{array}$ & -4 & +4 \\
\hline Material & STY 70 & SNCM 23 \\
\hline $\begin{array}{c}\text { Heat treatment } \\
\text { Finishing of tooth } \\
\text { surface }\end{array}$ & $\begin{array}{c}\text { Ground by maag gear grinder } \\
\text { heating }\end{array}$ & Cementation \\
\hline
\end{tabular}

昭和35年 3 月
無限幅の片持平板の任意の点に集中荷重が作用すると きの弾性理論を基碄とするものである．Fig. 1 に示す ような大さいクラウニングを施されている歯車におい ては，歯当りが局部的であるが，筋の端には過大な 歯元応力がおこらず，無限幅の片持平板に関する弾性 問題の解它用いてさしつかえない．以下にこの理論計 算によって得た歯元応力と，抵抗線ひずみ計によって 测定して得た霜元応力とについて考察する.

\section{（I）集中荷重による歯元応力分布}

まず，集中荷重を齿に加えた静荷重試験において， 歯筋にそった歯元応力分布を測定して，計算応力との 比較を試みた.

供試大雷車の歯形は Fig. 3 に示す基準ラックで創 成され，最弱断面齿厚は $20.8 \mathrm{~mm}$ である。この大歯 車に圧力角 $22^{\circ} 59^{\prime}$ の一枚歯のラゥクを用いて, Photo.

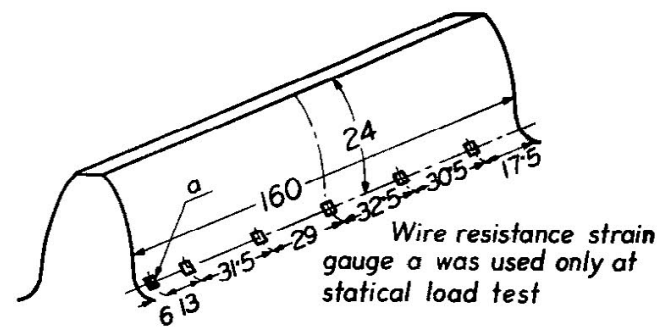

Fig. 2 Positions of wire resistance strain gauges at the tooth fillet of test gear

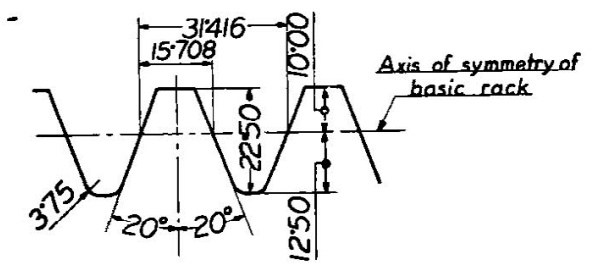

Fig. 3 Tooth form of basic rack of pinion and gear on the locomotive ED 6115

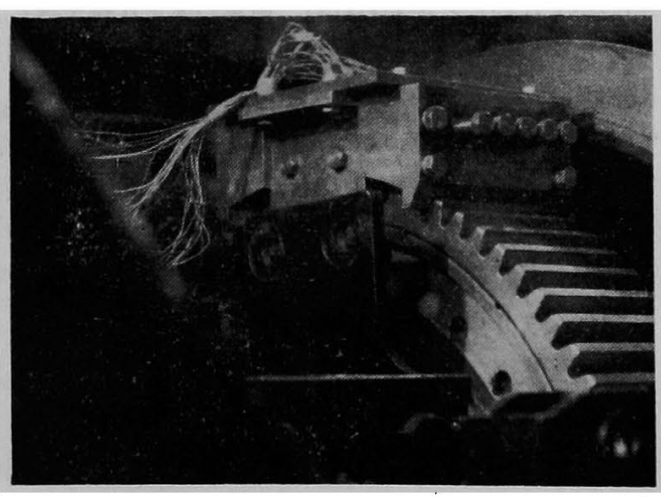

Photo. 1 Traction gear of electric locomotive, ED 6115, which prepared statical load test 
1 の静荷重負荷装置により集中荷重を加え，この場合 の崡元の齿筋方向応力分布を測定した：このラックに より齿に加えられた荷重は，接触面積中央が先先から $3 \mathrm{~mm}$ の位国で, 長輻 $3 \mathrm{~mm}$, 短軸 $1.5 \mathrm{~mm}$ のた形 状接触面を与える大きさであった。このラックは各ひ

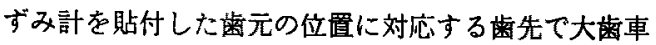
とかみ合うように5個使用した。 また，各うックによ り加えられる歯面荷重の大ささは，ラックの付根部に ひず就をはって，あらかじめラックに加えられる荷 重とそのひずみ計の出力との関係を求めておいて， Photo. 1 にみえる試験装置のボルトによりラックを 押して歯に荷重を負荷し，ラックのひずみ訴により崡 面に負荷される荷重を知った。このようにして求めた

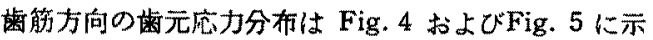
すとおりである．Fig. 4 は崡筋端から約 $50 \mathrm{~mm}$ 以上 離れたひずみ計により得た歯元応力分布, Fig. 5 は端 から約 $6 \mathrm{~mm}$ と約 $20 \mathrm{~mm}$ の位固のひずみ諨により測 定して得心歯元応力上，荷重点からひずみ棓までの距 離との関係示するのである。

Fig. 3のラックにより創成されるる歯形の最弱断面苗 厚を板厚とする，一様な厚さの然限幅をもつ平板を考 え，大歯車の静荷重試験において歯に加えられた分布 荷重を集中荷重として取り扱い，この崡面荷重と同じ 位置において平板に集中荷重が加わったとしたときの， 平板の固定端部曲げ応力を，応力集中を考箩しないで 計算により求めたものが Fig. 4 に示す曲線である。

このように幅の広い歯車で，齿筋の端から充分離れ た点に集中荷重が作用するときの，実測により得た雪 筋にそった齿元応力分布法，一様な板厚の聮限幅の片 持平板の理論諳十よる固算定端部応力分布之よく一致 している，さらに，片持平板の応力湘定結果をも参照 すると，Fig. 1 に示すように歯筋の端から $30 \mathrm{~mm}$ 以 上崡当りが生じないようにした本試瞼に供したクラウ ニンク゚齿車は，無限輻の片持平板として取り报ってさ しつかえないとが知られる。歯車の整を片持平板と 取り报って雪元応力計算により求める場合には，形

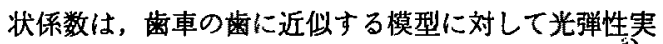
験により求めた Dolan の実駼結果を用いればよい. 本例の歯車に対して形状係数 $\alpha_{k}=1.9$ であり，本実

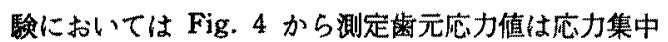
を考庿しない計算崡元応力值と一致した。

（II） クラウニンク齒車の計算菌元応力

齿車に集中荷重を加えた静荷重試駼を実施して，ひ ずみ計により測定される応力と計算応力との関係扣よ

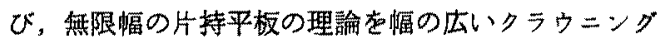
された齿車に適用することの妥当性を碓認し，さらに ひずみ計による湘定応力解析のために，理諭計算によ る歯元応力分布を求めた。歯元計算応力を求めるには，
荷重点ば枚歯かみ合いの範閒で，できるだけ齿先に 近い点とし，したがって，本例では刻み点をとり，こ のかみ合い位置の齿元応力を大歯車の称呼歯元応力と して取り报う.

歯車に加わる崡面荷重はHertzの理論に従って求め, この歯面分布荷重に対する歯元庥力をさきに導いた方 法に従がって求める．Fig. 6 はこのようにして求めた

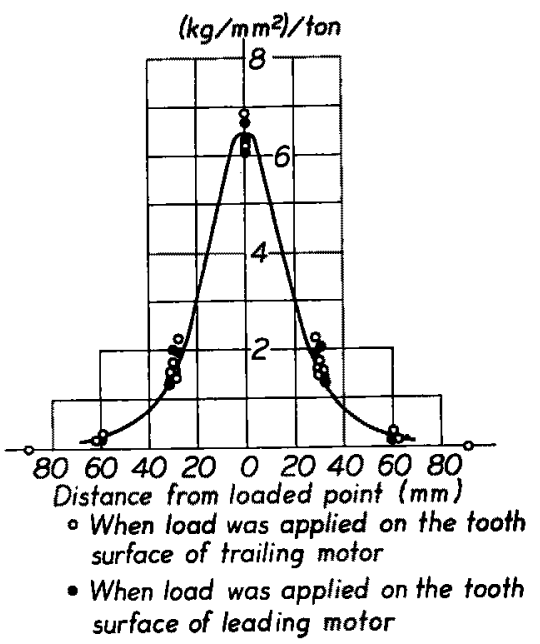

Fig. 4 Lengthwise stress distribution of gear by concentrated load. Loaded point is $3 \mathrm{~mm}$ apart from tooth top

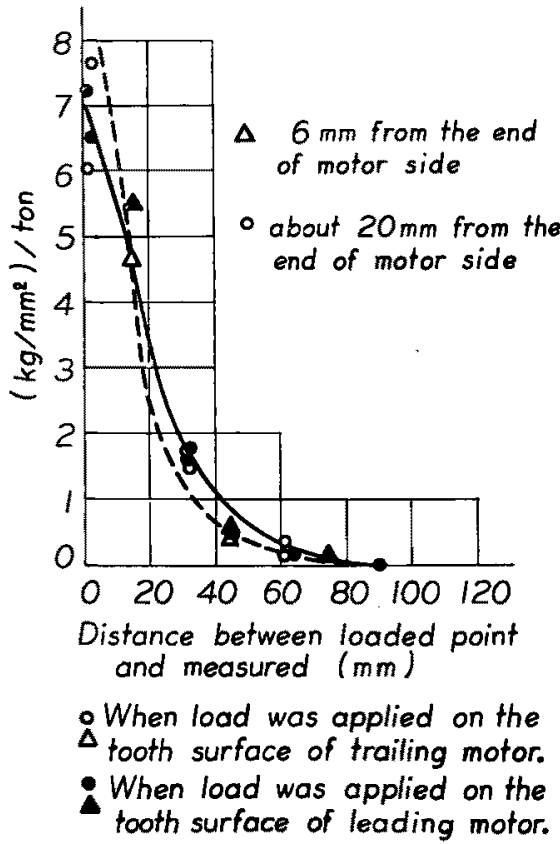

Fig. 5 Relation between the fillet stress of gear and the distance from loaded point to strain gauge which are placed near the end of tooth 
画面荷重と，その嘴荷重分布のときにおける応力集 中を考虑しない計算による圈元最大応力 $\sigma_{b}$ を歯車の 荷重，すなわち，電動機出カトルクに対して示したも

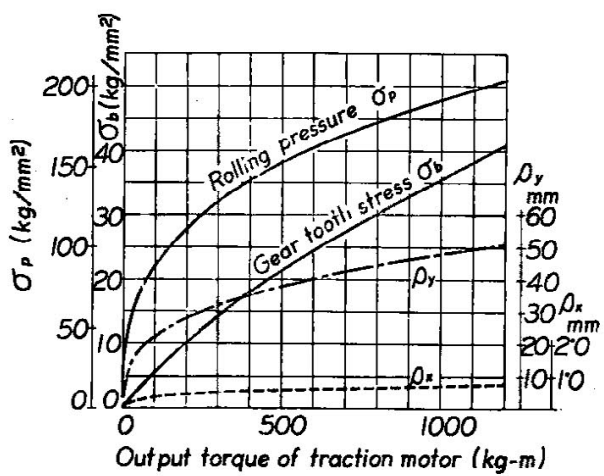

$2 \rho_{y}=$ Major axis of elliptic compressed area $20 \mathrm{x}=$ Minor axis of elliptic compressed area

Fig. 6 Gear tooth stress, rolling pressure and compressed area at the teeth contact versus output torque of traction motor
のである，同図において，歯面荷重は最大菌面接触応 力 $\sigma_{p}$ と, だ円接触面の半長軸 $\rho_{y}$ と半短軸 $\rho_{x}$ とで 示されている，この歯面荷重に対する歯元応力分布を 各電動機出力トルタ段階ごとに示したものが Fig. 7 である。

(III) 機関車走行中における齔元応力

さきに紹介したように，提抗線ひずみ計を貼付して

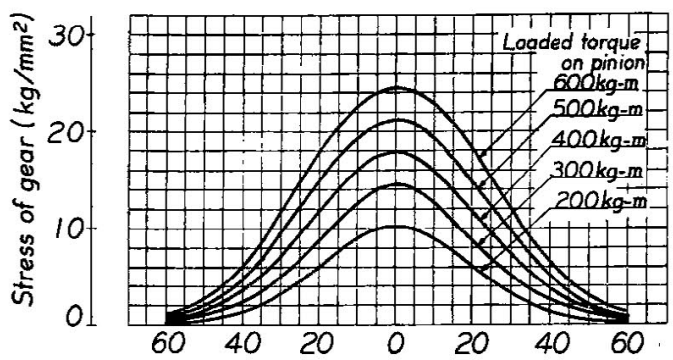

Distance from the center of tooth contact $(\mathrm{mm}$

Fig. 7 Calculated lengthwise stress distribution of gear (Fillet stress concentration is not considered)

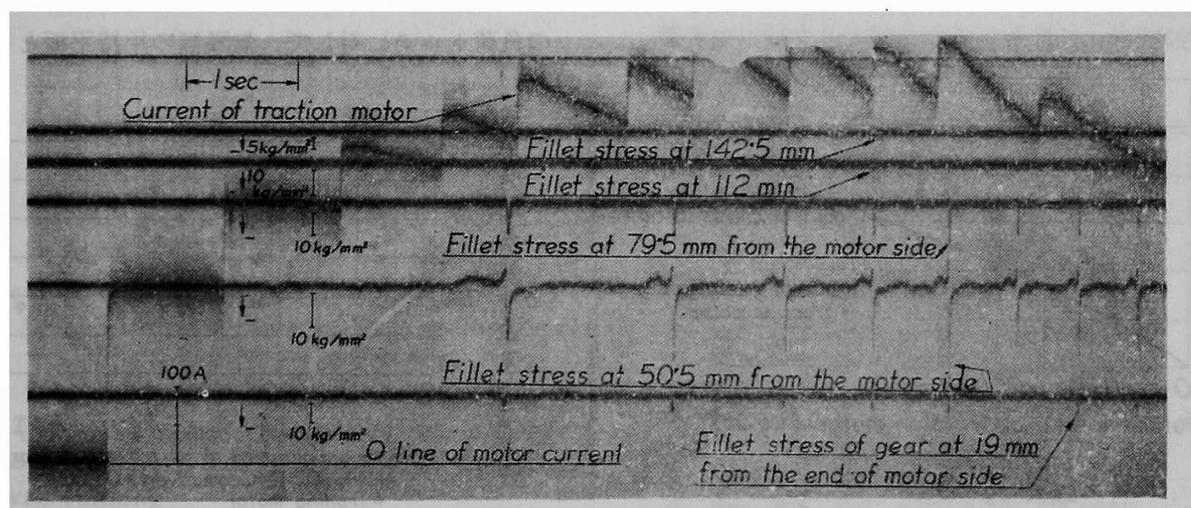

Photo. 2 Oscillogram of the lengthwise gear stresses at 5 points when the electric locomotive ED 6115 was running at the state of leading motor.

The motor was elastically mounted on the bogie

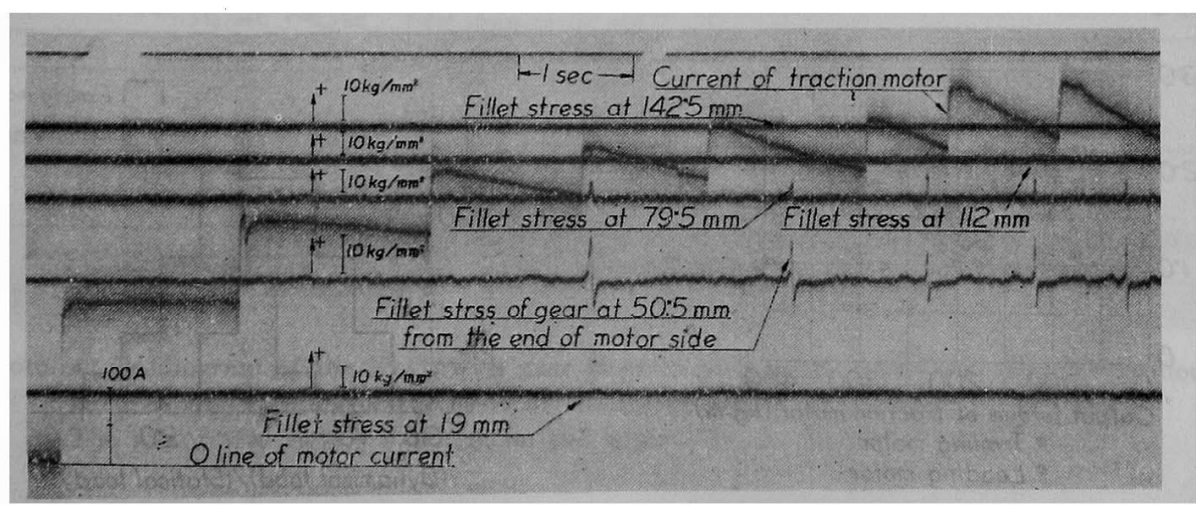

Photo. 3 Oscillogram of the lengthwise gear stresses at 5 points when the electric locomotive ED 6115 was running at the state of trailing motor.

The motor was elastically mounted on the bogie 
準備された大菌車をるつ電気機関車が，湘定用車两を 一両けん引して走行しているさいに，踩筋方向 5 力所 の歯元応力を同時に測定し，また，歯車の負荷荷重を 知るために電動機電流を測定しだ．Photo. 2 は機関 車進行方向に関して電動機が車輪より前側に位置して 機関車が進行する場合における崡元応力測定の才ッシ ログラム, Photo. 3 は Photo. 2 における進行方向 と逆方向の場合のオッシログラムである．これらのオ ッシロダラムから同閔間にお切る5力所の応力值と多 くの応力段階ごとに画かれた計算応力分有曲線とを比 較して，歯元最大応力を求め，そのときの電動機出力 トルクに対する関係で，前後進各 1 回ずつの出発のさ いに测定されたものを示したものが Fig. 8 である.

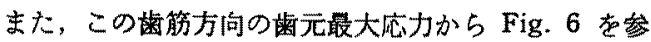
照して，その応力を生ぜさせるに必要な電動機トルク が知られる。この電動機トルクすなわち動荷重に対す る，電流から知られる静的負荷トルクの比が，大きい 量のクラウニングを施されている歯車においては，一 般にいわれている速度係数の逆数を与えるもので，

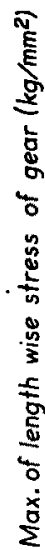

Fig. 8 Maximum of lengthwise distributed stress of gear versus torque of traction motor

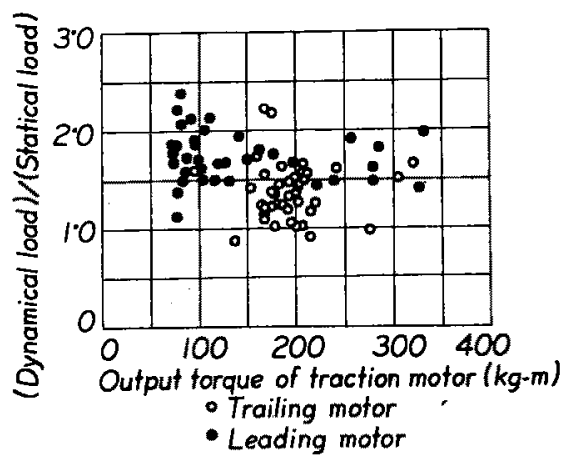

Fig. 9 Relation between the output torque of traction motor and the ratio of dynamical load versus statical load
Fig. 9 は電動機出力トルクと(動荷重)/(静荷重)との 関係を示し，Fig. 10 は歯車の刻み円における周速と (動荷重)/(静荷重)の関係を示したものである。この (動荷重)/(静荷重) の值の機䦛重 1 回の出発における 発生頻度はFig. 11 に示すとおりである.この比の值 は機関車の走行中における車輪のはげしい運動に影響 されて，その值は厷範囲に分布して和り，電磁オッシ ログラフを用い，4 KC の搬送波を抵抗線ひずみ計に 驸与した本測定に叔ては，最大 2.45 ，最小0.85て あった。

また，車輪が電動機に先行して機閏車が進行する場 合のほうが、この比の值が小さくてているが，これは 試運転線の都合で，両進行方向における測定区間を同 一埸所にとることがでさず，ために道床およびレール の条件が影響して，このように善が生じたものと考え られる。

このようにして歯筋方向で 5 力所の雪元応力を湘定 したが，これらの歯元応力分布を，荷重分布の中央点 な基华として，同し大ささの動荷重に対して示したる のが Fig. 12 である。この图におりる曲線はそれぞれ の負荷トルクに対して，無限幅の片持平板として計算

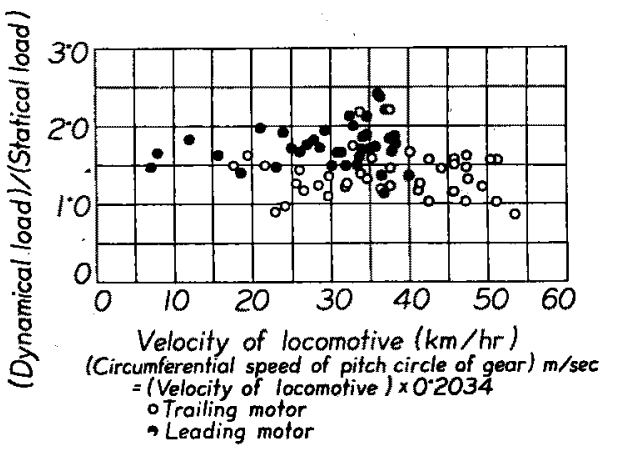

Fig. 10 Relation between the velocity of locomotive and the ratio of dynamical load versus statical load

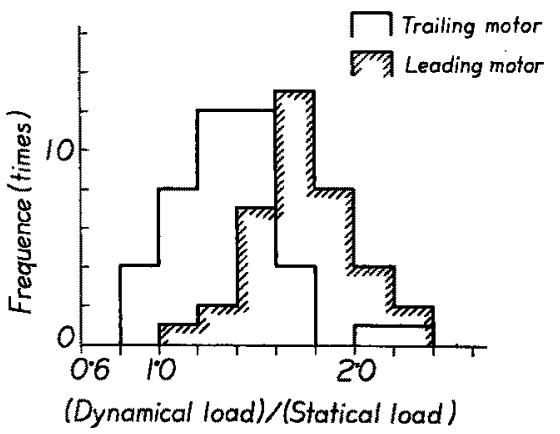

Fig. 11 Frequence of ratio of dynamical load versus statical load at one time of start of locomotive 
して得た歯元応力分布曲線であり，測定された歯元応 力分布と，計算して得たものとが上く一致することが 示されている.

他の電動機取付状態における走行試験にさいして，

Fig. 1 に示すような大きいクラウニングを施した歯車 であっても，大小歯車軸の平行度がきわめてわるいと， かみ合いを行なっている紫筋端の反対側における歯筋 端部で，トルク伝達の作用崡面の反対側歯面が接触を 行なっていることが Photo. 4 に示すオッシログラム から知られたこのような現象は楼車の応すに対し， また效率，騒音に対してきわめて悪影響を及ぼすもの である. 鉄道車両用けん引歯車では，一般に大小歯車 軸が正確に平行を保つようにすることがむずかしいも のであるが，その平行度に無関心ていると，この上う な現象が生じるので充分生意を要することを示す一例 である。

\section{4.むすび}

さきに大きい量のクラウニングを施し，楼筇端部に おいてはまったく片当りが生じないようにレリービン

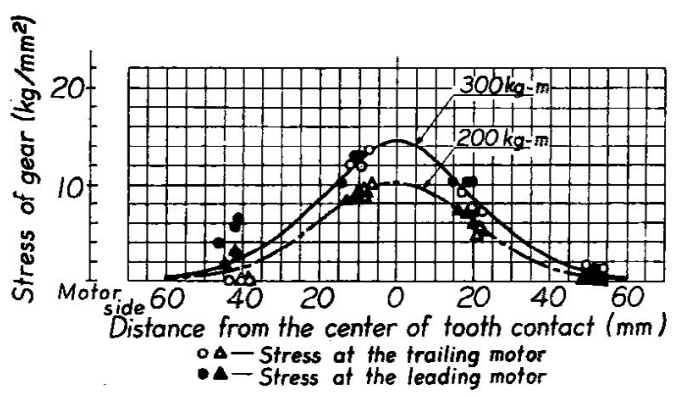

Fig. 12 Lengthwise stress distribution of gear for dynamical load when the locomotive was running
グが与えられている齒車に対して，その棶元応力の理 論的計算方法を導いたが，今回電気機関車用の小歯車 にのみ大きいクラウニングを施した歯車対において， 大菌車の歯元応力分布を測定することにより，つぎの 結論を得た。

（1）大きい量のクラウニングを施され，かつ歯筋 端部で片当りがおこらないようにレリービングを与え られている車両用歯車では，歯面荷重を Hertzの理論 に上り求め，この歯面荷重に対して，橉を無限幅の片 持平板におきかえて，歯元応力を計算する方法は，歯 元応力の大きさ，およびその分布状態を充分な精度で 与えるものである.

（2）車両用落車ではばね下質量の高い加速度の運 動が原因で，車両走行中の蔽車に加わる動荷重のばら つきは大きく，また，速度增加に伴なう(動荷重)/(静 荷重)の此の値の增加は, 比較的低速度の籁囲で実施 した本試験においては充分に認められなかった。

上記のように，機関車走行中の歯元応力を測定する ことにより，最近国有鉄道において使用されるように なった，車両用クラウニング崡車の理諭的齿元応力計

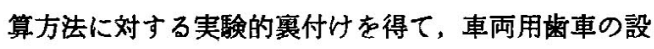
計法を与えることができた。

終りにあたり本実験を実施するために絶大な御援助 を睗わった東京芝浦電気株式会社府中工場の関係各位 に謝意を表する。

\section{参考文 献}

1）滕田，機棫等会論文篗，2€，163 (昭35.3)

2) 滕田, 材料試险, 8, 70, 599 (昭34)

3) T.J. Dolan, J. appl. Phys., 12, 584 (1941)

4) Buckingham, Analytical Mechanics of Gears, (1949), 486, McGraw-Hill

5) 明山, 歌川11, 日立评諭，33，585（昭31）

6) 明山，歌川，笠原，日立砰㻅，38，679(明31)

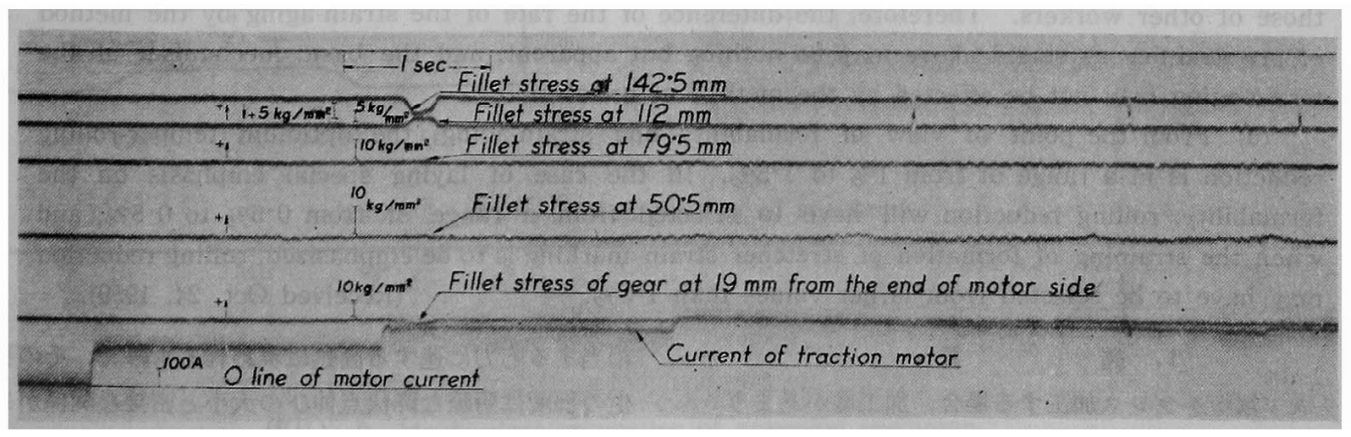

Photo. 4 Oscillogram of the lengthwise gear stresses at 5 points when the electric locomotive ED 6115 was running at the state of trailing motor.

The motor was rigidly mounted on the bogie 